\title{
Use of contraband cigarettes among adolescent daily smokers in Canada
}

\author{
Russell C. Callaghan PhD, Scott Veldhuizen BA, Scott Leatherdale PhD, Donna Murnaghan MN, \\ Steve Manske EdD
}

Previously published at www.cmaj.ca

\section{ABSTRACT}

Current tobacco-control strategies seek to inhibit and reduce smoking among adolescents. However, such strategies are probably undermined by the contraband tobacco market. Using data from Canada's 2006/2007 Youth Smoking Survey, we found that $13.1 \%$ of respondents who were daily smokers reported that contraband cigarettes were their usual brand. They consumed significantly more cigarettes than respondents who smoked other brands. Contraband cigarettes accounted for about $17.5 \%$ of all cigarettes smoked by adolescent daily smokers in Canada overall, and for more than $25 \%$ in the provinces of Ontario and Quebec.

A thriving contraband tobacco market has emerged in Canada, especially in Ontario and Quebec. ${ }^{1,2}$ Recent studies have estimated that $14 \%$ to $49 \%$ of all cigarettes bought by adult smokers in Ontario are illicit (i.e., purchased without the requisite provincial and federal taxes applied), originating primarily from First Nations reserves. Study methods have included population surveys of cigarette purchasing on reserves, ${ }^{1}$ interviews with smokers (sponsored by the tobacco industry $)^{3}$ and discrepancy analyses of taxation revenues against reported cigarette consumption. ${ }^{4}$

Whereas the existing literature has focused on adults, an assessment of youth involvement in the contraband market may be even more important. Contemporary tobacco-control policies seek to inhibit and reduce smoking among adolescents through price mechanisms (e.g., taxation) and minimum-age purchasing restrictions, ${ }^{5}$ strategies that the contraband market probably undermines. However, little is known about adolescents' use of contraband cigarettes.

\section{Methods}

We used data from 41886 high school students in grades 9 to 12 (ages 14-18 years) during the 2006/2007 school year who participated in Canada's 2006/2007 Youth Smoking Survey, a nationally representative classroom-based survey of public and private elementary and secondary school students in all 10
Canadian provinces. The survey sampled high schools using a multistage design based on stratification by smoking prevalence in each health region. Within each stratum, schools were randomly selected according to probabilities proportional to the total enrolment in their respective school boards. From the selected schools, $61 \%$ of eligible students participated.

We defined students as current daily smokers if they had smoked at least 100 cigarettes in their lifetime and reported smoking at least 1 cigarette per day on each of the 30 days preceding the survey.

Data about cigarette consumption were generated from the following survey question: "Thinking back over the last 30 days, on the days that you smoked, how many cigarettes did you usually smoke each day?" which had the following response categories: "a few puffs," 1, 2-3, 4-5, 6-10, 11-20, $21-29,30$ or more. To construct a quantitative estimate of monthly consumption, we used the midpoint for each range and 35 for " 30 or more."

To determine respondents' usual cigarette brand, the survey asked the question, "What brand of cigarettes do you usually smoke?" Respondents selected their responses from an alphabetical list of popular cigarette brands, which included "cigarettes from First Nations/Native brands" as the last option. We classified individuals who indicated "First Nations/Native brands" as their usual brand as current smokers of contraband cigarettes. We classified all other current daily smokers, including the 5\% who reported no usual brand, as current smokers of noncontraband cigarettes. For our analyses, we assumed that smokers of contraband cigarettes consumed only contraband brands and that smokers of

From the Centre for Addiction and Mental Health (Callaghan, Veldhuizen), Toronto, Ont.; the Dalla Lana School of Public Health (Callaghan, Leatherdale), University of Toronto, Toronto; the Department of Population Studies and Surveillance (Leatherdale), Cancer Care Ontario, Toronto; the Department of Health Studies and Gerontology (Leatherdale, Manske) and the Centre for Behavioural Research and Program Evaluation (Manske), University of Waterloo, Waterloo, Ont.; and the School of Nursing (Murnaghan), University of Prince Edward Island, Charlottetown, PEI

Cite as CMAJ 2009. DOI:10.1503/cmaj.090665 
noncontraband cigarettes smoked only noncontraband brands.

The Youth Smoking Survey used a complex analytical design. To account for unequal probability of selection among respondents, we bootstrapped all analyses using a set of replicate weights supplied with the survey data file.

\section{Results}

Among students in grades 9 to $12,5.2 \%$ (95\% confidence interval [CI] 5.0\%-5.3\%) were classified as current daily smokers. Of these, $13.1 \%$ (95\% CI $11.9 \%-14.3 \%$ ) reported First Nations/Native cigarettes as their usual brand. This proportion varied significantly by province $(p<0.001)$, with the highest rates in Ontario (21.8\%) and Quebec (22.4\%) (Table 1). Rates in the Prairie provinces were below $2.5 \%$ (the level below which, in the current study, exact reporting was prohibited by small cell sizes).

Smokers of First Nations/Native brand cigarettes reported significantly higher levels of consumption than other daily smokers (16.8 v. 11.9 cigarettes per day, $p<0.001)$. As a result, we estimated that First Nations/Native cigarettes accounted for about $17.5 \%$ (95\% CI 16.1\%-18.9\%) of all cigarettes smoked by daily smokers in secondary school in Canada.

\section{Interpretation}

Although the use of illicit substances by adolescents is well known, the use of contraband cigarettes in this age group is striking. Canadian tobacco-control policies have concentrated on preventing youths from starting to smoke. Given that adolescents' initiation and continuation of smoking behaviour are related to the availability and price of tobacco products, ${ }^{6,7}$ the availability of untaxed First Nations/Native cigarette brands, which typically sell for about \$3-\$4 per pack (about one-third the price of legiti- mate brands), undermines key tobacco-control strategies. The lower price and widespread availability of contraband cigarettes may also have clinical consequences, because smokers of contraband cigarettes are less likely than smokers of legitimate brands to attempt to quit or to achieve smoking cessation. ${ }^{8}$

A 2008 study by the Canadian Convenience Stores Association examined discarded cigarette butts at locations near 155 high schools in Ontario and Quebec. It concluded that $36 \%$ of those in Quebec and 26\% of those in Ontario were untaxed, counterfeit or foreign brands. ${ }^{9}$ Our study has added to this evidence by surveying students directly (to generate estimates of the number of young people involved) and by providing national estimates. In addition, our use of a population survey avoided possible selection effects inherent in the prior study, which was unable to determine whether the butts had actually been discarded by youths. Also, that study could not take into account other possible biases, such as differences between smokers of contraband cigarettes and smokers of other brands in terms of propensity to smoke in the surveyed locations or to dispose of butts improperly.

Our study had limitations. Individuals were assigned to groups on the basis of their choice of usual cigarette brand. Also, in our analyses we assumed that youths only smoked cigarettes within their preferred brand group. The students might have smoked a variety of brands; however, there are no data available on the extent of brand-switching between the contraband and noncontraband groups. In addition, the survey sampled only students. If the likelihood of smoking, and of using contraband cigarettes, differs for adolescents not enrolled in school, the accuracy of our estimates would be reduced.

The widespread use of First Nations/Native brand cigarettes, especially in Ontario and Quebec, presents a serious challenge to tobacco-control strategies, which attempt to use accessibility and price mechanisms to influence adolescents'

Table 1: Consumption of cigarettes and preference for contraband First Nations/Native brands among high school daily smokers in Canada

\begin{tabular}{|c|c|c|c|c|c|}
\hline \multirow[b]{2}{*}{ Province } & \multirow{2}{*}{$\begin{array}{l}\text { No. of } \\
\text { daily } \\
\text { smokers }\end{array}$} & \multirow{2}{*}{$\begin{array}{c}\%(95 \% \mathrm{Cl}) \text { of daily smokers } \\
\text { reporting First Nations/ } \\
\text { Native as "usual brand" }\end{array}$} & \multicolumn{2}{|c|}{$\begin{array}{c}\text { Brand group; } \\
\text { no. }(95 \% \mathrm{Cl}) \text { of cigarettes smoked daily }\end{array}$} & \multirow{2}{*}{$\begin{array}{c}\text { First Nations/Native brand } \\
\text { cigarettes as } \%(95 \% \mathrm{Cl}) \\
\text { of all cigarettes smoked* }\end{array}$} \\
\hline & & & Native brands & Other brands & \\
\hline $\begin{array}{l}\text { Newfoundland } \\
\text { and Labrador }\end{array}$ & 205 & $2.1 \quad(1.7-2.5)$ & $17.2(16.2-18.2)$ & $11.1(10.8-11.3)$ & $3.3 \quad(2.8-3.9)$ \\
\hline $\begin{array}{l}\text { Prince Edward } \\
\text { Island }\end{array}$ & 221 & $4.7 \quad(3.5-5.9)$ & $11.3(10.9-11.8)$ & $13.8(13.3-14.4)$ & $3.9 \quad(2.8-5.0)$ \\
\hline Nova Scotia & 274 & $7.8 \quad(6.7-8.9)$ & $13.7(12.8-14.7)$ & $13.6(13.3-13.9)$ & $7.9 \quad(6.9-9.0)$ \\
\hline New Brunswick & 1107 & $11.1(10.3-11.8)$ & $16.4(15.8-17.0)$ & $13.9(13.8-14.1)$ & $12.6(11.7-13.5)$ \\
\hline Quebec & 299 & $22.4(18.4-26.3)$ & $20.9(19.4-22.3)$ & 13.7 (12.7-14.8) & $30.0(26.1-33.9)$ \\
\hline Ontario & 384 & $21.8(19.4-24.1)$ & $15.4(14.2-16.7)$ & $12.1(11.5-12.6)$ & $26.3(23.5-29.2)$ \\
\hline Manitoba & 153 & NR & NR & $10.9(10.6-11.2)$ & NR \\
\hline Saskatchewan & 36 & NR & NR & $11.1 \quad(9.7-12.5)$ & NR \\
\hline Alberta & 31 & NR & NR & $12.5(10.7-14.2)$ & NR \\
\hline British Columbia & 139 & $3.5 \quad(2.5-4.5)$ & $15.9(10.2-21.5)$ & $9.8 \quad(9.0-10.6)$ & $(4.1-7.0)$ \\
\hline All of Canada & 2849 & $13.1(11.9-14.3)$ & $16.8(15.9-17.7)$ & $11.9(11.6-12.3)$ & $17.5(16.1-18.9)$ \\
\hline
\end{tabular}

Note: $\mathrm{Cl}=$ confidence interval, $\mathrm{NR}=$ not reportable because of small cell size.

*For daily smokers. 
smoking behaviour. Although the complex issues of First Nations jurisdiction would have to be recognized in any policy changes, ${ }^{10}$ Canadian tobacco-control strategies will need to address this issue.

This article has been peer reviewed.

Competing interests: None declared.

Contributors: Russell Callaghan and Scott Veldhuizen conceived of the study and oversaw all aspects of its completion. Scott Leatherdale, Donna Murnaghan and Steve Manske contributed to conceptualizing ideas, interpreting the findings and reviewing all versions of the manuscript. All of the authors approved the final version submitted for publication.

Acknowledgments: The Population Health Data Repository, University of Waterloo, graciously provided the data and bootstrapped weight files from the 2006/2007 Canadian Youth Smoking Survey. Under contract to the Tobacco Control Programme of Health Canada, the Centre for Behavioural Research and Program Evaluation at the University of Waterloo led a team of researchers across Canada to collect data for this survey. Data collection was conducted using SHAPES, a knowledge-exchange system funded by the Canadian Cancer Society. Matt Boire provided invaluable help in formatting the manuscript and the references. Dr. Pat Erickson alerted us to the important consideration of First Nations and American Indian jurisdiction in relation to tobacco production and use. Scott Leatherdale is a Cancer Care Ontario Research Chair in Population Studies.

Funding: This research was supported by an institutional grant from the Ontario Ministry of Health and Long-Term Care to the Centre for Addiction and Mental Health. The study sponsor had no role in the design of the study, the collection, analysis or interpretation of data, the writing of the report or the decision to submit the article for publication. The views expressed in this paper do not necessarily reflect those of the ministry.

\section{REFERENCES}

1. Luk R, Cohen JE, Ferrence R, et al. Prevalence and correlates of purchasing contraband cigarettes on First Nations reserves in Ontario, Canada. Addiction 2009; 104:488-95.

2. Royal Canadian Mounted Police, Customs and Excise Branch. 2008 contraband tobacco enforcement strategy. Ottawa (ON): Royal Canadian Mounted Police; 2008. Available: www.rcmp-grc.gc.ca/ce-da/tobacco-tabac-strat-2008-eng.htm (accessed 2009 June 22).

3. Illegal tobacco sales: a crisis for Canadians. National study for the Canadian Tobacco Manufacturers' Council. Mississauga (ON): GfK Research Dynamics; 2008. Available: www.imperialtobaccocanada.com/onewebca/sites/IMP_5TUJVZ.nsf /vwPagesWebLive/DO7L3L5T?opendocument $\&$ SID $=\& D T C=\& T M P=1$ (accessed 2009 June 22).

4. The Canadian tobacco market place. Estimating the volume of contraband sales of tobacco in Canada. Ottawa (ON): Physicians for a Smoke-Free Canada; 2008. Available: www.smoke-free.ca/pdf_1/EstimatesofContraband-2008.pdf (accessed 2009 June 22)

5. Liang L, Chaloupka F, Nichter M, et al. Prices, policies and youth smoking, May 2001. Addiction 2003;98(Suppl 1):105-22.

6. Ross H, Chaloupka FJ. The effect of cigarette prices on youth smoking. Health Econ 2003;12:217-30.

7. Glied S. Youth tobacco control: reconciling theory and empirical evidence. J Health Econ 2002;21:117-35.

8. Hyland A, Higbee C, Li Q. Access to low-taxed cigarettes deters smoking cessation attempts. Am J Public Health 2005;95:994-5.

9. Canadian Convenience Stores Association. Youth contraband tobacco study, 2008. Oakville (ON): The Association; 2008. Available: www.stopcontrabandtobacco.ca /buttstudy2en.pdf (accessed 2009 June 22).

10. Towards effective tobacco control in First Nations and Inuit communities. Ottawa (ON): Physicians for a Smoke-Free Canada; 2007. Available: www.smoke-free.ca /pdf_1/Effective\%20tobacco\%20control\%203.pdf (accessed 2009 June 22).

Correspondence to: Russell C. Callaghan, Centre for Addiction and Mental Health, 33 Russell St., Toronto ON M5S 2S1;

fax 416 595-6899; russell_callaghan@camh.net

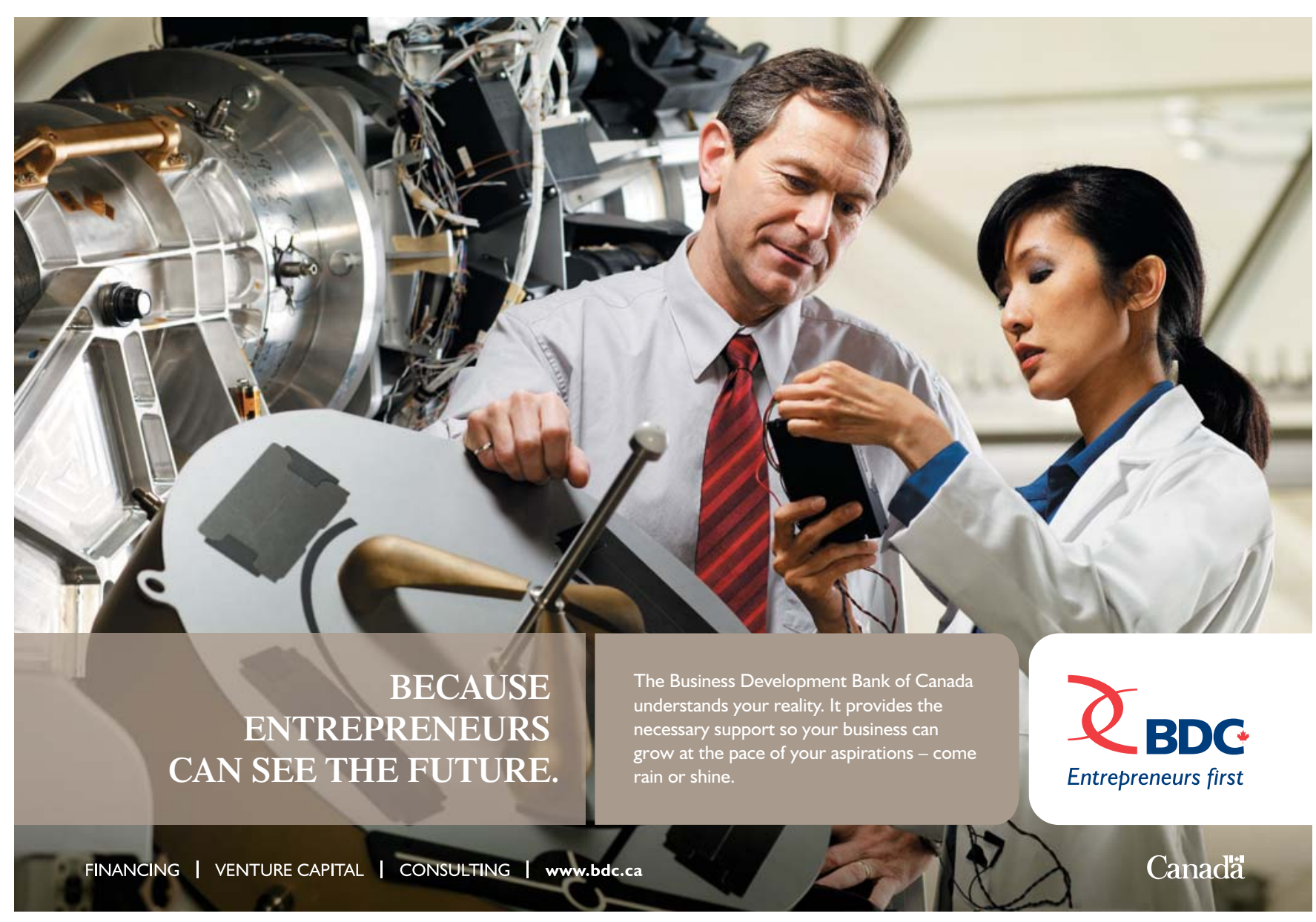

